\title{
HUBUNGAN ANTARA CULTURE SHOCK DENGAN PRESTASI BELAJAR PADA MAHASISWA PAPUA TAHUN PERTAMA YANG MERANTAU DI UKSW
}

\author{
SALATIGA \\ Elisabeth Tekege ${ }^{1}$, Berta Esti Ari Prasetya ${ }^{2}$ \\ Email: elisabethtekege16@gmail.com ${ }^{1}$ \\ Fakultas Psikologi Universitas Kristen Satya Wacana Salatiga ${ }^{1,2}$
}

\begin{abstract}
Abstrak
Kebudayaan dan lingkungan yang baru membuat individu seperti mahasiswa berada di dalam kondisi yang berbeda dari lingkungan daerahnya, perubahan ini apakah akan mengakibatkan prestasi belajar akan berada pada taraf yang baik atau tidak pada setiap mahasiswa yang merantau. Penelitian ini bertujuan untuk mengetahui hubungan antara culture shock dan prestasi belajar pada mahasiswa tahun pertama yang merantau di UKSW Salatiga. Metode penelitian dalam pengambilan sampel menggunakan teknik snowball sampling dengan melibatkan 102 mahasiswa angkatan 2019 yang berasal dari Papua. Pengambilan data melalui kuesioner yang disebarkan ke setiap responden dengan teknik analisa data menggunakan uji korelasi spearman's rho dengan bantuan aplikasi SPSS 26.0. Hasil penelitian menunjukkan nilai $r=0.068(\mathrm{P}>0,05)$ yang berarti tidak adanya hubungan signifikan antara culture shock dengan prestasi belajar. Dengan demikian hipotesis (H1) ditolak dimana hal ini menunjukkan bahwa tidak adanya hubungan yang singnifikan antara culture shock dan prestasi belajar.
\end{abstract}

Kata kunci: Culture Shock, Prestasi Belajar, Mahasiswa Merantau.

\begin{abstract}
The new culture and environment makes individuals such as students in different conditions from their local environment. This change will result in whether the learning achievement will be at a good level or not for each student who migrates. This study aims to determine the relationship between culture shock and learning achievement among first-year students who have migrated to SWCU Salatiga. The research method in sampling used the snowball sampling technique involving 1022019 class students who came from Papua. Retrieval of data through a questionnaire distributed to each respondent with data analysis techniques using thecorrelation test Spearman's rho with the help of the SPSS 26.0 application. The results showed the value of $r=0.068$ ( $P>0.05)$, which means there is no significant relationship between culture shock and learning achievement. Thus the hypothesis (HI) is rejected, which indicates that there is no significant relationship between culture shock and learning achievement.
\end{abstract}

Keywords: Culture Shock, Learning Achievement, Overseas Students.

\section{PENDAHULUAN}

Masa dewasa awal adalah saat dimana individu sudah menginjak usia 1840 tahun dengan terlihatnya perubahanperubahan kognitif, afektif, dan motorik sebagai pengaturan diri baru dalam masa transisinya masa remaja. Hurlock (1980) menyatakan bahwa masa anak-anak dan masa remaja merupakan periode pertumbuhan, sedangkan masa dewasa awal adalah periode pengaturan (settle down). Ketika memasuki masa pendidikan di perguruan tinggi individu mulai dikatakan memiliki keterampilan dalam mengolah cara berpikir, dimana hal tersebut sangat berkontribusi terhadap pertumbuhan kognitif. Menurut Montgomery \& Core (dalam Papalia, Feldman, \& Martorell, 2014) perguruan tinggi merupakan waktu untuk 
menemukan berbagai kecerdasan dan pertumbuhan individu, terutama dalam keterampilan verbal dan kuantitatif, berpikir kritis, dan penalaran moral. Ketika memasuki perguruan tinggi yang kompleks dan luas mahasiswa dituntut untuk mampu berpikir secara kritis dalam menghadapi dinamika lingkungan kampus seperti mengikuti organisasi-organisasi dan perkuliahan yang mungkin bisa berdampak pada prestasi belajar mahasiswa tersebut. Menurut Santrock (2007) proses transisi dari masa sekolah menengah akhir menuju perguruan tinggi juga melibatkan peralihan suatu struktur di sekolah yang lebih besar dan impersonal, yakni seperti berinteraksi dengan teman sebaya yang berbeda latar belakang budaya. Universitas Kristen satya wacana (UKSW) merupakan salah satu kampus yang berada di Salatiga dan dikenal dengan nama "Kampus Indonesia Mini” dikarenakan kampus menerima segala macam mahasiswa dari berbagai daerah di Indonesia seperti Kalimantan, Sulawesi, Sumatera dan salah satunya dari Papua terutama mereka yang ingin mengejar cita-citanya dengan mendapatkan pendidikan yang layak di daerah yang baru. Kompasiana (2015) mengatakan bahwa UKSW adalah salah satu universitas swasta tertua di Indonesia yaitu pada tahun 1956 yang berada di kota kecil di kaki gunung merbabu tepatnya di kota Salatiga, dimana terdapat banyak sekali mahasiswa dan civitas akademik yang berasal dari latar belakang budaya yang berbeda dengan daerah asal.

Ketika mahasiswa berada di lingkungan yang baru membuat individu bertemu dengan teman sebaya yang berbeda kebudayaan juga dari bahasa, logat, dan ras dimana karena hal tersebut membuat mahasiswa lebih malu bertemu dengan orang yang berbeda. Sejalan dengan pernyataan Schneiders (dalam Agustiani, 2006) menyatakan bahwa upaya respon mental dan tingkah laku individu berupaya keras agar mampu mengatasi konflik serta frustasi karena kurangnya kebutuhan dalam dirinya, sehingga bisa tercapai keselarasan dan keharmonisan dengan diri atau lingkungannya. Penyesuaian mahasiswa di tahun pertama menuntut untuk bisa berbaur dengan lingkungan baru namun dikarenakan perbedaan budaya mengakibatkan kesenjangan dalam perkuliahan terkhususnya mereka yang merantau dari luar kota dan pulau. Salah satu yang menyebabkan mahasiswa mulai merantau adalah ingin mendapatkan pendidikan yang layak dikarenakan di tempat daerah asal individu tidak 
mendapatkan pendidikan yang sesuai dan layak, sehingga mahasiswa mulai merantau di luar pulau demi menggapai cita-citanya (Kompasiana, 2015).

Mahasiswa yang merantau di luar pulau ingin mendapatkan pendidikan yang layak dan berkualitas yang mana hal ini sangat berpengaruh pada prestasi mereka di tanah rantau. Mahasiswa-mahasiswa dari Papua yang marantau sudah mulai mencari tempat yang sesuai untuk menimbah ilmu di daerah lain yang memiliki sarana dan prasarana yang memadai untuk mendalami ilmu di jenjang yang lebih tinggi, sehingga dapat membangun Papua kearah yang lebih baik lagi dari sebelumnya. Banyak alasan yang mendasari para pelajar mulai melanjutkan studi ke perguruan tinggi di Jawa. Karena rendahnya kualitas pendidikan di daerah terpencil, terutama di wilayah Indonesia bagian Timur yang meliputi sarana dan prasarana yang kurang dan belum memadai, kualitas dari guru dan tenaga pengajar lain juga dirasa masih belum kompeten menjadi salah satu alasan mahasiswa mulai merantau ke Pulau Jawa dan pulau lainnya yang lebih baik untuk mendapatkan pendidikan yang lebih layak (Kompasiana, 2016). Hal ini didukung dengan pernyataan yang diberikan oleh Universitas Gajah Mada (2014) dimana sebanyak $6 \%$ mahasiswa yang berkuliah di PTN mulai mencari pendidikan yang layak karena pendidikan di Papua belum dirasa maksimal selain dari pemerintahnya sendiri disebabkan juga karena rendahnya kualitas pengajar dan sarana yang dialokasikan buat pendidikan di Papua, sehingga menyebabkan peluang untuk mendapatkan pendidikan yang layak itu tidak dijalankan secara semestinya. Hal ini yang menyebabkan kebanyakan mahasiswa Papua memutuskan untuk menempuh pendidikan baik di luar kota atau pulau. Mahasiswa yang menempuh pendidikan di luar daerahnya asal dalam jangka waktu yang lama disebut juga dengan istilah mahasiswa merantau (Halim \& Dariyo 2016). Ketika seseorang sudah mulai melanjutkan studi di perguruan tinggi berarti ada keinginan untuk memperoleh pengetahuan yang lebih baik dan mendalam di dunia pendidikan dengan salah satu caranya yaitu untuk meningkatkan prestasi belajarnya di kampus. Menurut Dess (dalam Suryabrata, 2002) prestasi belajar adalah hasil yang didapat dari aktivitas belajarnya. Selanjutnya Sudjana (1990) mengatakan bahwa prestasi belajar adalah hasil belajar dari kemampuan-kemampuan yang dimiliki seseorang setelah menerima pengalaman belajarnya. Sedangkan 
Hamalik (2005) dalam bukunya Proses Belajar Mengajar menyebutkan prestasi belajar merupakan kemampuan seseorang dalam memproses suatu kegiatan yang bersifat individual, dimana prestasi belajar ini memiliki unsur-unsur penilaian suatu usaha atau kecakapan yang dicapai dari proses pembelajaran bukan hanya pengubahan penguasan dalam setiap latihan melainkan juga pada pengubahan kelakuan. Keberhasilan seorang siswa dalam prestasi belajarnya dapat dilihat dari bentuk rapor ataupun IPK (Indeks Prestasi Kumulatif) yang di dapatkan dan penilaian prestasi ini bersangkutan dengan tiga aspek yaitu kognitif, afektif, dan psikomotorik yang menggambarkan kemampuan seseorang dalam proses belajar serta juga memberikan pemahaman atau pengetahuan yang baru bagi individu itu sendiri. Di Papua sendiri prestasi belajar sudah mulai meningkat dengan adanya program dari pemerintah untuk mendanai setiap mahasiswa asli papua dengan memberikan bantuan beasiswa demi meningkatkan sumber daya manusia di papua. Dalam Antaranews (2019) sebanyak 26 anak asli Papua diberikan bantuan beasiswa bagi mahasiswa berprestasi untuk melanjutkan pembelajaran mereka ke Rusia hal ini menunjukkan adanya keseriusan yang diberikan oleh pemerintah kepada anakanak asli Papua dalam menggapai cita-cita dan meningkatkan sumber daya manusia (SDM). Dalam hal ini adanya peran pemerintah dalam mengembangkan prestasi belajar mahasiswa sangat penting karena dari mahasiswa tersebutlah yang akan membangun kota Papua kearah yang lebih maju lagi.

Faktor-faktor yang memengaruhi prestasi belajar yaitu karena faktor dari internal dan eksternal, dimana internal sendiri terdiri dari faktor fisiologis, Kecerdasan atau Intelegensi, bakat, minat, perhatian, motivasi, sikap. Kalau faktor eksternal terdiri dari keluarga, sekolah dan masyarakat (Slameto, 1988). Dalam hal peran internal dan eksternal dalam meningkatkan prestasi belajar sangat penting terutama saat individu merantau di daerah yang baru, salah satunya yang sangat berpengaruh yaitu motif dimana hal tersebut berarti ada tujuan yang ingin dicapai dan untuk mencapai itu terjadi proses pembelajaran dimana individu mampu mendorong dirinya, sedangkan ketika mahasiswa berada dalam masa transisi seperti mengalami perbedaan budaya membuat individu merasa terbebani dengan perbedaan budaya dimana salah satunya karena culture shock. 
Culture shock merupakan suatu proses aktif dalam menghadapi suatu perubahan saat berada di lingkungan yang kurang familiar yaitu merupakan bentuk dari culture shock yang dimana proses aktif itu meliputi ABC (Affect, Behaviour and Cognitions) individu merasa, berpikir, dan berperilaku ketika menghadapi budaya yang berbeda (Ward dkk, 2001). Dengan kata lain, culture shock bisa terjadi jika ketika tiga aspek (Affect) berkaitan dengan perasaan dan emosi, (Behaviour) dinamika sosial dalam bentuk komunikasi verbal dan nonverbal dan (Cognitions) cara individu menilai dan berpikir tentang dirinya dan orang-orang yang ada disekitarnya yang bisa mempengaruhi seseorang ketika berada dilingkungan budaya yang berbeda seperti perbedaan budaya, suku, bahasa, makanan dan sebagainya (Ward, 2001). Suatu korelasi antara culture shock dengan prestasi belajar bisa tercapai ketika individu mampu mengendalikan dirinya di lingkungan yang baru, dimana ketika culture shock semakin tinggi maka akan berpengaruh pada prestasi belajar yang menurun, namun sebaliknya jika culture shock menurun maka prestasi belajar yang didapatkan akan meningkat. Pernyataan tersebut sesuai dengan Ward dkk (2001) yang menyatakan bahwa perilaku yang tidak tepat secara budaya dapat menimbulkan kehidupan personal dan profesional individu tersebut menjadi tidak efektif ketika mahasiswa rantau menjadi kurang berprestasi secara akademis. Dengan demikian ketika individu kurang mampu menyesuaikan dirinya di lingkungan baru akan bisa berdampak pada diri dan juga prestasi belajarnya.

Oleh karena itu, dari pembahasan diatas peneliti mulai tertarik dan ingin meneliti kembali tentang hubungan antara culture shock dengan prestasi belajar pada mahasiswa Papua yang merantau di UKSW Salatiga.

\section{KAJIAN PUSTAKA}

\section{Prestasi Belajar}

Hamalik (2005) prestasi belajar merupakan kemampuan seseorang dalam memproses suatu kegiatan yang bersifat individual, dimana prestasi belajar ini memiliki unsur-unsur penilaian suatu usaha atau kecakapan yang dicapai dari proses pembelajaran bukan hanya pengubahan penguasan dalam setiap latihan melainkan juga pada pengubahan kelakuan.

$$
\text { Hamalik (2005) mengatakan }
$$
bahwa prestasi belajar dikategorikan dalam tiga aspek yaitu: 
a. Ranah kognitif, meliputi kemampuan pengetahuan, pemahaman, penerapan, analisis, sintesis, dan evaluasi.

b. Ranah afektif, meliputi perilaku penerimaan, sambutan, penilaian, organisasi dan karakterisasi.

c. Ranah psikomotorik meliputi kemampuan motorik berupa persepsi, kesiapan, gerakan terbimbing, gerakan terbiasa, gerakan kompleks, penyesuaian pola gerakan dan kreativitas.

Slameto (1988) mengatakan ada beberapa faktor yang memengaruhi prestasi belajar digolongkan menjadi 2 yaitu faktor internal dan eksternal:

1. Faktor internal

a. Faktor Fisiologis

Faktor fisiologis adalah faktor yang berhubungan dengan kondisi fisik individu. Kondisi fisik berhubungan dengan kondisi pada organ-organ tubuh yang berpengaruh pada kesehatan.

b. Faktor Psikologis

Dimana diantaranya berupa kecerdasan, perhatian, minat, bakat, motif, kematangan, kesiapan.

c. Faktor Kelelahan

Kelelahan sendiri terdiri dari dua macam yaitu kelelahan jasmani dan rohani, seperti stamina lemah atau kurang fit.

\section{Faktor eksternal}

a. Faktor Keluarga

Keluarga merupakan tempat pertama kali anak merasakan pendidikan, karena di dalam keluargalah anak tumbuh dan berkembang dengan baik, sehingga secara langsung maupun tidak langsung keberadaan keluarga akan mempengaruhi keberhasilan belajar anak.

b. Faktor Sekolah

Sekolah merupakan lembaga pendidikan formal pertama yang sangat penting dalam menentukan keberhasilan belajar siswa, karena itu lingkungan sekolah yang baik dapat mendorong untuk belajar lebih giat.

c. Faktor Masyarakat

Masyarakat sangat berpengaruh terhadap prestasi siswa dimana hal tersebut bisa terjadi karena keberadaannya di sekitar kita yang meliputi kegiatan yang ada di dalam masyarakat, media massa, teman bergaul, dan bentuk kehidupan di masyarakat itu sendiri yang mana akan berakibat pada prestasi belajar individu.

\section{Culture Shock}

Ward, dkk (2001) suatu proses aktif dalam menghadapi suatu perubahan saat berada di lingkungan yang kurang familiar yaitu merupakan bentuk dari culture shock yang dimana proses aktif itu meliputi ABC (Affect, Behaviour and 
Cognitions) individu merasa, berpikir, dan berperilaku ketika menghadapi budaya yang berbeda.

Menurut Ward, dkk (2001) mengatakan bahwa culture shock berasal dari tiga aspek yaitu:

a. Afektif (Affective)

Dimensi ini mencakup perasaan serta emosi yang dimana mungkin menjadi positif atau negatif. Dalam hal ini individu mengalami kebingungan dan merasa kewalahan dikarenakan tiba di lingkungan yang asing, sehingga individu merasa bingung, cemas, disorientasi, curiga, dan bahkan sedih ketika berada di lingkungan yang asing.

\section{b. Perilaku (Behavior)}

Elemen dari ini adalah komunikasi verbal dan nonverbal yang menjadi pokok penting untuk sebuah pertimbangan dinamika sosial dan efek dari kontak budaya yang menunjukkan bahwa banyak dari proses-proses ini bervariasi antara kelompok budaya dan etnis.

c. Kognitif (Cognitive)

Dasar konseptual sebagian besar diambil dari teori-teori kognisi sosial yang berhubungan dengan cara-cara individu menilai dan berpikir tentang diri mereka sendiri dan orang disekitarnya, termasuk bagaimana individu memproses informasi yang ada disekitar kelompok mereka sendiri (in-kelompok) dan sekitar kelompok lain (out-kelompok).

\section{METODE PENELITIAN}

Penelitian ini menggunakan pendekatan kuantitatif dengan metode penelitian korelasional. Dalam penelitian ini terdapat 2 variabel yaitu variabel bebas (X) dan variabel terikat (Y). Variabel independen (bebas) dalam penelitian ini yaitu Culture Shock (X) dan Variabel dependen (terikat) dalam penelitian ini yaitu Prestasi Belajar (Y). Penelitian ini dilakukan di Universitas Kristen Satya Wacana Salatiga, Jawa Tengah. Partisipan dalam penelitian ini berjumlah 102 orang mahasiswa/i UKSW angkatan 2019 yang merantau dari Papua. Teknik pengambilan sampel yang digunakan adalah snowball sampling.

Alat ukur dalam penelitian ini menggunakan skala culture shock dan prestasi belajar. Skala culture shock diadaptasi dan dimodifikasi dari Purba (2017). Hasil uji seleksi culture shock menunjukkan bahwa dari 50 aitem pertanyaan, terdapat 36 aitem yang valid dan 14 aitem yang gugur, dengan nilai korelasi bergerak antara 0.254 paling rendah dan 0,681 paling tinggi. Hasil uji reliabilitas pada skala culture shock menunjukkan nilai koefisien 0,904. Unutk skala prestasi belajar diadaptasi dari Sihite 
(2012) dalam pengambilan data tidak digunakan seleksi item dan reliabilitas pada skala prestasi belajar karena data yang didapatkan berupa nilai akademik (IPK) dari proses belajar mengajar di kampus, data yang ada juga diperoleh dari persetujuan subjek penelitian karena bersifat pribadi dengan jumlah sebanyak 102 mahasiswa tahun pertama yang berasal dari Papua di UKSW Salatiga.

\section{HASIL DAN PEMBAHASAN}

\section{Culture Shock}

Skala culture shock dalam penelitian ini menggubakan 4 kategori yang mana terdiri dari sangat rendah, rendah, tinggi, dan sangat tinggi dimana subjek yang mengalami culture shock sangat rendah berjumlah ada 15 orang dengan nilai presentasi $15 \%$, kemudian subjek yang mangalami culture shock pada kategori rendah berjumlah 79 orang dengan nilai presentasi $77 \%$. Subjek dengan kategori tinggi berjumlah 6 orang dengan nilai presentasi $6 \%$, sedangkan kategori sangat tinggi berjumlah 2 orang dengan nilai presentasi 2\%. Dari data yang diperoleh menunjukkan nilai ratarata (mean) sebesar 75,35 dengan kata lain data tersebut menunjukan bahwa mahasiswa tahun pertama yang berasal dari Papua memiliki culture shock yang rendah. Skor yang didapatkan bergerak dari skor minimum sebesar 52 hingga skor maximum sebasar 128 dan standard deviasi 12,487.

\section{Prestasi Belajar}

Untuk prestasi belajar ada 4 kategori yang dipakai yaitu tidak memuaskan, memuaskan, sangat memuaskan, cumlaude dimana subjek yang mengalami prestasi belajar tidak memuaskan berjumlah ada 33 orang dengan nilai presentase $32 \%$, kemudian subjek yang mengalami prestasi belajar pada kategori memuaskan berjumlah 30 orang dengan nilai presentasi $29 \%$. Subjek dengan kategori sangat memuaskan berjumlah 31 orang dengan nilai presentasi 30\%, sedangkan kategori cumlaude berjumlah 8 orang dengan nilai presentasi $8 \%$. Dari data yang diperoleh menunjukkan nilai rata-rata (mean) sebesar 2,33 dengan kata lain data tersebut menunjukan bahwa mahasiswa tahun pertama yang berasal dari Papua memiliki prestasi belajar yang tidak memuaskan. Skor yang didapatkan bergerak dari skor minimum sebesar 27 hingga skor maximum sebasar 67 dan standard deviasi 0,994 .

\section{Uji Asumsi}

Sebelum melakukan uji hipotesis dengan teknik korelasi, maka dilakukan terlebih dahulu uji asumsi yaitu uji 
normalitas (Kolmogorov Smirnov), uji linearitas (Anava) dan uji korelasi spearman's rho.

\section{Uji Linearitas}

Hubungan kedua variabel bisa dikatakan linear jika p>0,05 dan dikatakan tidak linear jika $\mathrm{P}<0,05$. Dari hasil yang didapatkan diketahui menunjukan bahwa adanyanya hubungan yang linear antara culture shock dengan prestasi belajar pada mahasiswa tahun pertama dari Papua yang berkuliah di UKSW Salatiga dimana nilai $\mathrm{F}=1,466$ dengan nilai signifikan $\mathrm{p}=$ $0,089(\mathrm{p}>0,05)$.

\section{Uji Normalitas}

Dari hasil uji normalitas diketahui data pada kedua variabel tidak berdistribusi normal dimana, culture shock diperoleh $\mathrm{KS}-\mathrm{Z}=0,000(\mathrm{p}<0,05)$ dan pada variabel prestasi belajar diperoleh KS-Z = 0,026 ( $\mathrm{p}<0,05)$.

\section{Uji Korelasi spearman's rho}

Berdasarkan hasil yang diperoleh setelah melakukan pengujian mengunakan korelasi spearman rho diperoleh nilai nilai korelasi $r=0,068$ dengan nilai signifikan berada pada skor 0,250 $(>0,05)$ dengan demikian dapat dikatan bahwa tidak adanya hubungan yang signifikan antara culture shock dan prestasi belajar. Hal berarti hipotesis menyatakan variabel culture shock dan prestasi belajar ditolak.
Dimana hipotesis awal menyatakan adanya hubungan antara culture shock dengan prestasi belajar pada mahasiswa tahun pertama yang merantau di UKSW Salatiga. Penelitian ini bertujuan untuk mengetahui hubungan antara culture shock dengan prestasi belajar pada mahasiswa Papua tahun pertama yang berkuliah di UKSW Salatiga, berdasarkan hasil uji korelasi diketahui $r=0,068$ dengan signifikan $\mathrm{p}=0,250(\mathrm{p}>0,05)$ yang berarti tidak adanya hubungan signifikan antara culture shock dengan prestasi belajar. hipotesis awal ditolak karena terlihat adanya kecenderungan mahasiswa Papua tahun pertama yang merantau di Salatiga berusaha untuk beradaptasi di lingkungan barunya. Hal ini sejalan dengan hasil dari kategorisasi skala culture shock dengan perbandingannya seperti $77 \%$ mahasiswa memiliki culture shock yang rendah, $15 \%$ memiliki culture shock yang sangat rendah, 6\% mahasiswa memiliki culture shock yang tinggi, sedangkan $2 \%$ mahasiswa memiliki culture shock pada tingkat yang tinggi. Ward (2001) yang merumuskan culture shock sebagai proses aktif individu ketika menghadapi perubahan lingkungan yang terdiri dari dimensi affective, behavior, dan cognitive yaitu bagaimana orang merasa, berperilaku, dan berpikir ketika 
menghadapi perubahan kedua budaya. Seperti yang dikatakn sebelumnya ketika setiap individu yang mengalami culture shock merupakan suatu hal yang wajar dikarekan perubahan lingkungan yang berbeda di masa-masa awal saja seperti budaya yang berbeda. Mahasiswa yang berkuliah di pulau yang berbeda dari asal sebelumnya dituntut untuk mampu bisa beradaptasi serta menjalin komunikasi yang baik dengan lingkungan yang baru seperti di lingkungan tempat tinggal ataupun lingkungan kampus. Hal ini sejalan dengan Devinta dkk (2015) yang mengatakan mahasiswa Jawa yang menempuh pendidikan di UNITRI bisa melakukan penyesuaian diri untuk mengatasi culture shock dengan aktif menjalani komunikasi dengan mahasiswamahasiswa yang berada di kampus serta luar kampus. Dikarenakan berada pada kesatuan negara yang sama membuat bahasa yang dipakai mudah dipahami dan menjadi suatu patokan dalam beradaptasi dengan budaya yang baru. Dimana menurut Kaplan (2002) adaptasi tidak juga terlepas dari ekologi budaya diatara seperti sistem budaya serta intuisi-intuisi dalam suatu budaya atau saling menyesuaikan satu sama lainnya. Dengan kata lain, menyebabkan terjadinya hubungan antara culture shock dengan prestasi belajar tidak menunjukkan hubungan yang signifikan antara kedua variabel. Hal ini sejalan juga dengan penelitian yang dilakukan oleh Mitasari \& Istikomayanti (2018) yang menyatakan tidak adanya hubungan antara culture shock dengan hasil belajar dikarenakan mahasiswa baru telah melakukan adaptasi yang baik dengan lingkungan disekitarnya. Hal ini bisa terjadi karena mahasiswa bisa berinteraksi serta berkomunikasi dengan mahasiswa dari daerah atau budaya yang berbeda, dengan mengikuti setiap kegiatan serta organisasi yang ada di kampus UKSW.

Selain itu, ditemukan bahwa prestasi belajar berada di tingkat yang memuaskan pada mahasiswa Papua tahun pertama yang merantau di UKSW Salatiga dengan nilai prestasi belajar, 32\% mahasiswa memiliki prestasi belajar yang tidak memuaskan, 29\% mahasiswa memiliki prestasi belajar yang memuaskan, $30 \%$ mahasiswa memiliki prestasi belajar pada tingkat yang sangat memuaskan, serta $8 \%$ mahasiswa berada pada tingakat prestasi belajar yang cumlaude. Dimana prestasi belajar bukanlah sesuatu yang sederhana namun kompleks yang mana dipengaruhi oleh faktor-faktor yang tidak dapat dikendalikan. Menurut Fitriyah (2018) 
selain dari faktor internal seperti fisiologis dan psikologis ada juga faktor intelektif yaitu unsur-unsur kepribadian tertentu seperti sikap, kebiasaan, motivasi, emosi, kebutuhan dan penyesuaian diri. Selain dari faktor-faktor diatas ada juga faktor yang dapat mempengaruhi prestasi belajar seseorang yaitu fasilitas belajar dengan tersediannya sarana dan prasarana seperti ruangan kelas, perpustakaan, media penyampaian materi, dan sebagainya. Djamarah (2002) fasilitas belajar juga menentukan keberhasilan belajar seorang siswa. Ketika suatu tempat memiliki fasilitas yang baik maka dalam pembelajarannya pun akan meningkat terkhususnya prestasi belajar. Menurut Azwar (2009) mengatakan bahwa interkasi yang terjadi dari berbagai faktor tersebutlah yang menjadi determinan atau penentu bagaimana hasil dari proses belajar yang dialami oleh individu. Hal ini bisa terjadi karena masing-masing faktor tidak selalu sama dalam mengkontribusi suatu faktor yang ditentukan dari kehadiran faktor lainnya dan sangat bersifat situasional.

Dari hipotesis yang di dapatkan dari penelitian yang sudah dilakukan menyatakan bahwa hubungan antara culture shock dan prestasi belajar tidak memiliki hubungan yang signifikan antara kedua variabel. Hal ini sejalan dengan penelitian yang dilakukan oleh Sihite (2012) dalam penelitiannya pada mahasiswa asing asal Malaysia di fakultas kedokteran Universitas Sumatera Utara mengatakan bahwa tidak adanya hubungan yang signifikan antara culture shock dengan prestasi belajar dikarenakan terdapat kecenderungan mahasiswa asing yang bisa beradaptasi dengan lingkungan barunya. Ada beberapa faktor yang lebih mempengaruhi prestasi belajar yaitu tempat tinggal dan lingkungan individu tersebut seperti kost, rumah kontrakan atau asrama yang mana hal ini bisa memperkuat ikatan antara setiap individu. Ansiga (2012) tidak adanya hubungan antara culture shock dengan prestasi belajar bisa di sebabkan juga oleh berbagai faktor yang kuat seperti tempat tinggal atau lingkungan, serta kelengkapan orang tua. Dimana hal ini berarti bahwa ketika individu memiliki tempat tinggal, lingkungan, serta keluarga yang baik maka akan tercapinnya keselarasan antara kedua variabel.

\section{PENUTUP}

\section{Kesimpulan}

Berdasarkan hasil penelitian di atas maka peneliti dapat menyimpulkan bahwa penelitian ini tidak menunjukkan hubungan yang signifikan antara culture 
shock dan prestasi belajar pada mahasiswa Papua tahun pertama yang merantau di UKSW Salatiga. Hasil penelitian ini juga menunjukkan bahwa diperoleh bahwa sebagian besar mahasiswa Papua tahun pertama yang berkuliah di UKSW Salatiga memiliki culture shock yang rendah dan prestasi belajar yang berada pada kategori memuaskan.

\section{Saran}

Diharapkan bagi mahasiswa yang berada di daerah yang baru terkhususnya mahasiswa yang merantau bisa menselaraskan culture shock yang baik dengan budaya-budaya yang berada disekitarnya serta diharapkan juga bagi mahasiswa Papua yang berkuliah di Salatiga bisa memiliki minat belajar yang tinggi dalam proses pembelajaran di perkuliahan sehingga prestasi belajarnya bisa meningkat dan mendapatkan nilai (IPK) yang baik. Bagi Peneliti selanjutnya Dapat digunakan sebagai suatu acuan tambahan referensi untuk keperluan penelitian selanjutnya dan dilakukan penelitian lebih lanjut berdasarkan faktor lainnya seperti faktor lingkungan, tempat tinggal individu, jumlah sampel yang lebih banyak, dan tempat yang berbeda.

\section{DAFTAR PUSTAKA}

Agustiani, H. 2006. Psikologi perkembangan: Pendekatan ekologi kaitannya dengan konsep diri dan penyesuaian diri pada remaja. Bandung: Refika Aditama.

Ansiga, F. M. 2012. Hubungan antara culture shock dan prestasi akademik pada mahasiswa asal Papua. (Skripsi). Universitas Sanata Dharma. Yogyakarta.

Arikunto, S. 2006. Prosedur suatu pendekatan praktek. Jakarta: Rineka Cipta.

Azwar, S. 2008. Penyusunan skala psikologi. Yogyakarta: Pustaka Pelajar.

Azwar, S. 200). Sikap Manusia dan Teori Pengukurannya. Edisi ke-2. Jakarta: Pustaka Pelajar.

Devinta, M., Hidayah, N., dan Hendrastomo, G. 2015. Fenomena Culture Shock (Gegar Budaya) pada Mahasiswa Perantauan di Yogyakarta. Jurnal Pendidikan Sosiologi, 1-15.

Dua puluh enam anak Papua dapat beasiswa belajar ke Rusia. 2019. September 29). Antaranews.com. diunduh dari: https://www.antaranews.com/berita/ 1087408/26-anak-papua-dapatbeasiswa-belajar-ke-rusia.

Djamarah, S. B. 2002. Rahasia sukses belajar. Jakarta: Rineka Cipta.

Enam Persen Mahasiswa Asal Papua Kuliah di PTN. (2014, Juni 02). Universitas Gajah Mada. Diunduh dari

https://www.ugm.ac.id/id/berita/90 16-6-persen-mahasiswa-asal-papuakuliah-di-ptn.

Enam alasan mereka merantau. (2013, September 22). Kompasiana. Diunduh dari 
https://www.kompasiana.com/suci ana/5528f9986ea834b15b8b4590/ 6-alasan-mereka-merantau.

Fitriyah, W. 2018. Pengaruh Motivasi dan Tingkat Pendidikan Orang Tua terhadap Prestasi Belajar Siswa MI Muhammadiyah 19 Sidokumpul Lamongan (Doctoral dissertation, Universitas Islam Negeri Maulana Malik Ibrahim).

Halim, C. F., \& Dariyo, A. 2016. Hubungan psychological well-being dengan loneliness pada mahasiswa yang merantau. Jurnal Psikogenesis, 4(2).

Hamalik, O. 2005 Proses belajar dan mengajar. Jakarta: Bumi Aksara.

Hurlock, E. B. 1980. Psikologi perkembangan suatu pendekatan seoanjang rentang kehidupan. Jakarta: Erlangga.

Indonesia, R. 2014. Peraturan Menteri Pendidikan dan Kebudayaan RI Nomor 49 Tahun 2014 tentang Standar Nasional Pendidikan Tinggi Pasal 1 Ayat 7. Sekretariat Negara. Jakarta.

Kaplan, D., \& Manner, R. 2002. Teori Budaya, terjemahan Landung Simatupang: Yogyakarta. Pustaka Pelajar.

Kebudayaan, S. P. M. P. D. 2014.

Republik Indonesia. Standar

Nasional Pendidikan Tinggi.

Masalah Pendidikan Di Indonesia Timur. (2015, Juni 17). Kompasiana. Diunduh dari https://www.kompasiana.com/infot ercepatku/55817f7f149773a536fb6 f20/masalah-pendidikan-diindonesia-timur?page $=$ all.
Mitasari, Z., \& Istikomayanti, Y. 2018. Hubungan antara culture shock dengan hasil belajar mahasiswa tahun pertama. Jurnal Psikologi Pendidikan dan Konseling: Jurnal Kajian Psikologi Pendidikan dan Bimbingan Konseling, 4(2), 105113.

Papalia, D. E., Feldman, R. D., \& Martorell, G. 2014. Menyelami Perkembangan Manusia (12 ed., Vol. 2). (F. W. Herarti, Trans.) Salemba Humanika.

Purba, I. K. 2017. Hubungan Culture Shock dengan Motivasi Belajar pada Mahasiswa Perantau Universitas Sumatera Utara Angkatan 2016 yang Berasal dari Luar Pulau Sumatera. (Skripsi) Universitas Sumatera Utara: Medan

Santrock, J. W. 2007. Child development. New York: McGrow.

Sihite, Y. A. S. 2012. Hubungan Culture Shock Dengan Prestasi Belajar Pada Mahasiswa Asing Di Fakultas Kedokteran Universitas Sumatera Utara. Sumatera Utara.

Slameto, B. 1988. Faktor-faktor yang mempengaruhinya, Jakarta: PT. Bina Aksara.

Sudjana, N. (199). Penilaian hasil proses belajar mengajar. PT Remaja Rosdakarya.

Sugiyono, D. R. 2006. Statistika untuk penelitian. Bandung: $\mathrm{CV}$. Alfabeta.

Suryabrata, S. 2002. Psikologi pendidikan. Jakarta: PT. Raja Grafindo Perseda.

Syah, M. 2010. Psikologi pendidikan dengan pendekatan baru. Bandung: PT Remaja Rosdakarya. 
Ward, Collen dan Stephen Bochnar \& Adrian Furnham. 2001. The Psychology Culture Shock, 2nd Edition. USA: Taylor \& Francis, Inc.

Rahayu, P. P., \& Hartati, S. (2015, Oktober). Dukungan sosial ayah dengan penyesuaian sosial pada remaja laki-laki. Jurnal empati, 4, 334-339.

Saputri, M. A., \& Indrawati, E. S. (2011, April). Hubungan antara dukungan sosial dengan depresi pada lanjut usia yang tinggal di Panti Wreda Wening Wardoyo Jawa Tengah. Jurnal Psikologi Undip, 9.

Sumara, D., Humaedi, S., \& Santoso, M. B. (2017, Juli). Kenakalan remaja dan penanganannya. Jurnal Penelitian \& PPM, 4, 129-389.

Tarmidi, \& Rambe, A. R. (2010, Desember). Korelasi antara dukungan sosial orang tua dan self-directed learning pada siswa SMA. Jurnal Psikologi, 37, 216223.

Wandansari, Y. (2004, Desember ). Peran dukungan orang tua dan guru terhadap penyesuaian sosial anak berbakat intelektual. Jurnal Provitae, 1. 